\title{
Curcumol triggers apoptosis of p53 mutant triple-negative human breast cancer MDA-MB 231 cells via activation of p73 and PUMA
}

\author{
LANZHEN HUANG ${ }^{1}$, ANG LI $^{1}$, GUANZHEN LIAO ${ }^{1}$, FEICHENG YANG ${ }^{1}$, \\ JING YANG $^{1}, \mathrm{XU} \mathrm{CHEN}^{2}$ and XIAOSHAN JIANG ${ }^{1,3}$ \\ ${ }^{1}$ Center for Science Research; ${ }^{2}$ School of Pharmacy; and ${ }^{3}$ Graduate College, \\ Guilin Medical University, Guilin, Guangxi 541004, P.R. China
}

Received August 21, 2015; Accepted March 7, 2017

DOI: $10.3892 / \mathrm{ol} .2017 .6273$

\begin{abstract}
Triple-negative breast cancer (TNBC; estrogen receptor-negative, progesterone receptor-negative and Her-2-negative) is often accompanied by a higher frequency of p53 gene mutations. Therefore, TNBC is challenging to treat due to a lack of biological targets and a poor sensitivity to conventional therapies. Curcumol is a monomer composition isolated from the ethanol extracts of Curcuma wenyujin, a Chinese medicinal herb traditionally used as a cancer remedy. Previous studies have revealed that curcumol is able to block proliferation in various human tumor cell lines. However, the underlying mechanisms have yet to be elucidated. The present study aimed to investigate the anticancer effects of curcumol in the human p53 mutant TNBC MDA-MB-231 cell line and its underlying mechanisms. Cell viability and growth were determined by MTT and a mice xenograft model assay, respectively. Cell cycle distribution was examined by flow cytometry. Apoptosis was evaluated by apoptotic morphology analysis with DAPI staining and flow cytometric analysis following Annexin V/propidium iodide staining. The protein expression in cells was evaluated by immunoblotting. Treatment of MDA-MB-231 cells with curcumol resulted in a significant inhibition of cell proliferation in vitro [half maximal inhibitory concentration $\left(\mathrm{IC}_{50}\right)=240.7 \pm 85.0 \mu \mathrm{g} / \mathrm{ml}$ for $48 \mathrm{~h}$ and $\mathrm{IC}_{50}=100.2 \pm 13.5 \mu \mathrm{g} / \mathrm{ml}$ for $72 \mathrm{~h}$. Curcumol treatment also resulted in the suppression of xenograft growth in vivo (100 or $200 \mu \mathrm{g} / \mathrm{kg}$ for 21 days), as well as $G_{1}$ phase arrest and an apoptotic response, which were accompanied by the upregulation of $\mathrm{p} 73$ expression and the activation of the expression of p53 upregulated modulator
\end{abstract}

Correspondence to: Dr Xiaoshan Jiang, Graduate College, Guilin Medical University, Hong-De Building, 109 North 2nd Huan-Cheng Road, Guilin, Guangxi 541004, P.R. China

E-mail: jiangxs@glmc.edu.cn

Abbreviations: $\mathrm{IC}_{50}$, half maximal inhibitory concentration; PI, propidium iodide; PUMA, p53 upregulated modulator of apoptosis; TNBC, triple-negative breast cancer

Key words: curcumol, apoptosis, anticancer, p73, PUMA, breast cancer, MDA-MB-231 of apoptosis (PUMA) and Bcl-2 antagonistic killer (Bak). No cleavage of poly (ADP-ribose) polymerase was detected. To the best of our knowledge, the present data demonstrate for the first time that curcumol inhibits the growth of MDA-MB-231 cells and triggers p53-independent apoptosis, which may be mediated by the p73-PUMA/Bak signaling pathway. Curcumol may, therefore, be a potential compound for use in the development of novel TNBC therapeutics.

\section{Introduction}

Triple-negative breast cancer (TNBC; estrogen receptor-negative, progesterone receptor-negative and Her-2-negative) remains challenging to treat due to the innate aggressive biological characteristics and the lack of effective therapies $(1,2)$. TNBCs represent $\sim 15 \%$ of all breast cancer cases and are often accompanied by a higher frequency of p53 gene mutations $(2,3)$. The tumor suppressor gene p53 serves a critical role in conferring cancer cell sensitivity to DNA-damaging agents (3). Failure of p53 signaling leads to resistance to chemotherapeutics (3-5). p73 is a member of the p53 gene family. Under certain conditions, p73 is able to replace the p53 function in response to DNA damage, activate the transcription of p53-responsive genes and inhibit cell growth in a p53-like manner by inducing cell cycle arrest and apoptosis (6-8). Therefore, the identification of anticancer drugs able to activate p73 and target p53 downstream genes may provide a chemotherapeutic approach for the treatment of p53-deficient types of cancer.

Curcuma is a traditional Chinese herbal medicine, which may be subgrouped into Curcuma aeruginosa Roxb and Curcuma wenyujin Y. H. Chen et C. Ling (Curcuma wenyujin). Curcuma is traditionally used to treat various ailments, including cacochylia, traumatic hematoma, parasitic infection and tumorous diseases (9). The essential oils of Curcuma wenyujin exhibit antitumor, anti-inflammatory, antioxidant and antimicrobial characteristics with low cytotoxicity and are embodied in the official Pharmacopoeia of the P.R. China as an anticancer and antiviral remedy $(10,11)$. A total of six volatile compounds (curdione, curcumol, germacrone, curzerene, 1,8-cineole and $\beta$-elemene) have been successfully isolated from the essential oil of Curcuma wenyujin (12). As one of the major components of the essential oil, curcumol, 
$\mathrm{C}_{15} \mathrm{H}_{24} \mathrm{O}_{2-}$ (3s-(3a, 3aa,5a,6a,8ab))-octahydro-3-methyl-8-methylene-5-(1-methylethyl)-6h-3a, 6-epoxyazulen-6-ol (13), has been reported to be capable of blocking the proliferation of various types of human tumor cells, including lung, prostate and ovarian cancer cell lines in vitro and inducing apoptosis via a caspase-independent mitochondrial pathway in ASTC-a-1 cells (14-17). However, the molecular mechanisms underlying curcumol-induced anti-proliferative effects are still unknown. In addition, little is currently understood regarding the anticancer effect of this compound on breast cancer cells. The present study investigated the anticancer properties of curcumol in vitro and in vivo using human p53 mutant TNBC MDA-MB-231 cells and BALB/c nu/nu mice. The data revealed that curcumol inhibits the proliferation and xenograft growth of MDA-MB-231 cells, and triggers cell apoptosis via a p53-independent pathway involved in the upregulation of p73 and the activation of the pro-apoptotic genes p53 upregulated modulator of apoptosis (PUMA) and B-cell lymphoma-2 (Bcl-2) antagonistic killer (Bak). These findings demonstrate the potential of curcumol as a therapeutic agent towards TNBC.

\section{Materials and methods}

Animals, cell lines and materials. In total of 24 female 4-week-old BALB/c nu/nu (nude) mice ( 15 g) were purchased from the Experimental Animal Centre of the Shanghai Institutes for Biological Sciences (Shanghai, China) and raised in SPF conditions; the experimental protocol of the present study was approved by the Guilin Medical University Ethics Committee for Animal Experimentation (Guilin, China). The MDA-MB-231 and MCF-7 cell lines was donated by Dr P. Wedegeartner (Thomas Jefferson University, Philadelphia, PT, USA), but originally obtained from the American Type Culture Collection (Manassas, VA, USA).

Curcumol (purity $>99 \%$ by high performance liquid chromatography, lot no. P02-03) was purchased from Shanghai Aihui Bio-Tech Co., Ltd. (Shanghai, China) and dissolved in ethanol at a concentration of $100 \mathrm{mg} / \mathrm{ml}$. MTT, propidium iodide (PI), RNase A, DAPI and adriamycin were purchased from Sigma-Aldrich (Merck KGaA, Darmstadt, Germany). Annexin V-fluorescein isothiocyanate (FITC) Apoptosis Detection kit was purchased from BD Biosciences (San Jose, CA, USA). Rabbit anti-p53 (cat. no., sc-53394), -p21 (cat. no., sc-397), -p73 (cat. no., sc-7975) and poly (ADP-ribose) polymerase (PARP)-1 polyclonal antibodies (cat. no., sc-7150), and mouse anti-BAK (cat. no., sc-1035), PUMA (cat. no., sc-374223) and Actin (cat. no., sc-8432) monoclonal antibodies were purchased from Santa Cruz Biotechnology, Inc. (Dallas, TX, USA) and used at a dilution of 1:1,000. Goat anti-rabbit (cat. no., W4011) and anti-mouse (cat. no., W4021) immunoglobulin $\mathrm{G}(\mathrm{H}+\mathrm{L})$-horseradish peroxidase-conjugated secondary antibodies were purchased from Promega Corporation (Madison, WI, USA) and used at a dilution of 1:5,000. An Enhanced Chemiluminescence Detection kit was obtained from Pierce (Thermo Fisher Scientific, Inc., Waltham, MA, USA). All cell culture plates were purchased from Corning Incorporated (Corning, NY, USA).

Cell culture. The TNBC MDA-MB 231 cell line was cultured in Dulbecco's modified Eagle's medium (HyClone; GE Healthcare Life Sciences, Logan, UT, USA) supplemented with $10 \%$ fetal bovine serum (Gibco; Thermo Fisher Scientific, Inc.), $100 \mu \mathrm{g} / \mathrm{ml}$ streptomycin and $100 \mathrm{U} / \mathrm{ml}$ penicillin (HyClone; GE Healthcare Life Sciences) at $37^{\circ} \mathrm{C}$ in a humidified atmosphere containing $5 \% \mathrm{CO}_{2}$. When cells were $\sim 50 \%$ subconfluent, the cells were treated with $12.5-800 \mu \mathrm{g} / \mathrm{ml}$ of curcumol (stock $100 \mathrm{mg} / \mathrm{ml}$ dissolved in ethanol). Untreated MDA-MB-231 cells served as a control and were cultured following a similar protocol in medium supplemented with equivalent volumes of ethanol (vehicle).

MTT assay for cell viability. An MTT assay (Sigma-Aldrich; Merck KGaA) was used to assess cellular viability reflected by the metabolic activity of the cells. The cells were seeded on 96-well plates at a density of 4,000 cells/well. Following an incubation at $37^{\circ} \mathrm{C}$ overnight, the cells were exposed to curcumol at concentrations of $12.5,25,50,100,200$, 400 and $800 \mu \mathrm{g} / \mathrm{ml}$ for 48 and $72 \mathrm{~h}$. Ethanol served as the control. Subsequent to the indicated time points, $10 \mu \mathrm{l}$ MTT ( $5 \mathrm{mg} / \mathrm{ml}$ dissolved in PBS, $\mathrm{pH}$ 7.4) was added to each well and incubated at $37^{\circ} \mathrm{C}$ for $4 \mathrm{~h}$. Following incubation, the culture medium was aspirated and the plates were dried by inversion at room temperature for $\sim 15 \mathrm{~min}$. The formazan crystals were then dissolved using dimethyl sulfoxide (100 $\mu$ l for each well) and the absorbance was measured at $510 \mathrm{~nm}$ using an iMark microplate absorbance reader (Bio-Rad Laboratories, Inc., Hercules, CA, USA). All assays were performed in quadruplicate and each experiment was conducted five times. Cell inhibition was calculated using the following formula: Inhibition rate $(\%)=[1-(\mathrm{OD}$ test/OD control) $] \times 100$. Optical density (OD) represents the absorbance value. The half maximal inhibitory concentration $\left(\mathrm{IC}_{50}\right)$ was calculated using SPSS version 20.0 (IBM SPSS, Armonk, NY, USA).

Xenograft model assay. BALB/c nu/nu mice were randomly assigned into three groups with eight mice per group, and maintained in the specific-pathogen-free Animal Facility at Guilin Medical University. A total of $1 \times 10^{7} \mathrm{TNBC}$ MDA-MB-231 cells were suspended in $0.2 \mathrm{ml} \mathrm{PBS}$ and injected subcutaneously into the right flank of the nude mice. The mice were intraperitoneally injected with curcumol (100 or $200 \mu \mathrm{g} / \mathrm{kg}$ ) every $48 \mathrm{~h}$ after developing measurable tumors. The tumor growth was monitored every 3 days and the mice were sacrificed by cervical dislocation on the $21 \mathrm{st}$ day subsequent to i.p. injection. Tumors were then dissected and weighed.

Cell cycle analysis. TNBC MDA-MB-231 cells were seeded in $6 \mathrm{~cm}$ (diameter) dishes, synchronized by serum deprivation at $37^{\circ} \mathrm{C}$ for $96 \mathrm{~h}$. Cells were then exposed to 25 or $100 \mu \mathrm{g} / \mathrm{ml}$ curcumol for 20 and $24 \mathrm{~h}$, respectively, at $37^{\circ} \mathrm{C}$. Cells treated with an equal volume of ethanol at $37^{\circ} \mathrm{C}$ were used as a control. At the designated time points (20 and $24 \mathrm{~h}$ after exposure to curcumol), adherent cells were harvested by trypsinization and floating cells were collected by centrifugation $(3,000 \mathrm{x} \mathrm{g}$, $5 \mathrm{~min}$, room temperature). Cells were fixed in $70 \%$ ethanol overnight at $4^{\circ} \mathrm{C}$ and then treated with a staining buffer (PBS containing $1 \mathrm{mg} / \mathrm{ml} \mathrm{PI}$ and $10 \mathrm{mg} / \mathrm{ml} \mathrm{RNase} \mathrm{A)} \mathrm{at} 37^{\circ} \mathrm{C}$ in the dark for $30 \mathrm{~min}$. The DNA content of the cells was determined by analyzing 10,000 ungated cells using FACSAria ${ }^{\text {TM }}$ III flow cytometer (BD Biosciences, San Jose, CA, USA) and 

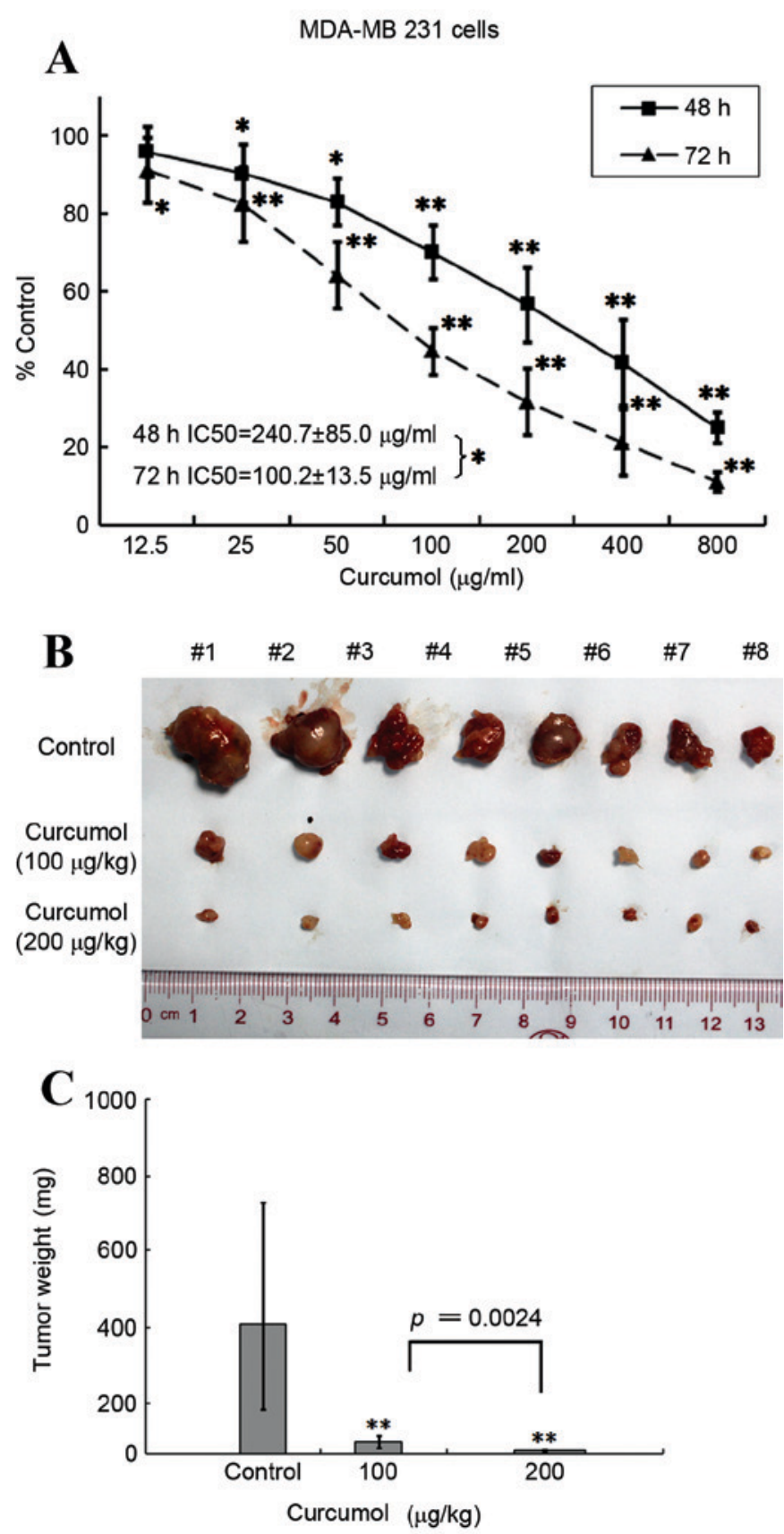

Figure 1. Suppression of TNBC MDA-MB 231 cell growth by curcumol. (A) MTT assay demonstrated that the viability of MDA-MB-231 cells significantly decreased following treatment with curcumol in a dose- and time-dependent manner. The results are representative of five independent experiments performed in quadruplicate. (B) Growth of MDA-MB-231 xenografts were inhibited by curcumol. Mice with MDA-MB-231 xenografts were randomly divided into three groups $(n=8)$ and treated intraperitoneally with curcumol (100 and $200 \mu \mathrm{g} / \mathrm{kg}$ ) or vehicle control every other day for 21 days. The mice were then sacrificed and the tumors were excised, weighed and images were captured. (C) The tumor weight comparison histogram of the control and curcumol treatment groups. Data are presented as the mean and the error bars represent the standard deviation. ${ }^{*} \mathrm{P}<0.05,{ }^{* *} \mathrm{P}<0.01$ vs. vehicle control. TNBC, triple-negative breast cancer.

FACSDiva $^{\text {Tw }}$ software version 6.1.3 (BD Biosciences). The experiment was performed in triplicate.

Morphological analyses. TNBC MDA-MB-231 cells were seeded onto 6-well plates containing microscope coverslips at a density of $4 \times 10^{5}$ cells/well. Following an overnight incubation at $37^{\circ} \mathrm{C}$, cells were treated with 50,100 or $200 \mu \mathrm{g} / \mathrm{ml}$ curcumol or with the matched ethanol vehicle and incubated for an additional $48 \mathrm{~h}$ at $37^{\circ} \mathrm{C}$. Cells were then fixed in $0.4 \%$ PBS-buffered paraformaldehyde solution for $15 \mathrm{~min}$, stained with DAPI for $5 \mathrm{~min}$ at room temperature and mounted on microscope slides. The morphology of the cell nuclei was observed at an excitation wavelength of $350 \mathrm{~nm}$ using a laser confocal fluorescence microscope (LSM710 Meta; Carl Zeiss AG, Oberkochen, Germany). The percentage of apoptotic cells (cells with nuclear condensation and/or fragmentation) was evaluated by randomly counting $\geq 10$ fields for each condition.

Annexin V/PI-staining. MDA-MB-231 cells were seeded onto 6-well plates at a density of $4 \times 10^{5}$ cells/well. After $24 \mathrm{~h}$, cells were treated with 50,100 and $200 \mu \mathrm{g} / \mathrm{ml}$ curcumol. Following 18,24 or $36 \mathrm{~h}$ exposure to curcumol, the cells were collected and analyzed using the Annexin V-FITC Apoptosis Detection kit (BD Biosciences) according to the manufacturer's instructions. Briefly, the cells were trypsinized, washed with PBS and resuspended in $100 \mu \mathrm{l}$ buffer solution $(10 \mathrm{mM}$ Hepes/ $\mathrm{NaOH}$ at $\mathrm{pH} 7.4,140 \mathrm{mM} \mathrm{NaCl}, 2.5 \mathrm{mM} \mathrm{CaCl} 2$ ) at a final concentration of $1 \times 10^{6}$ cells $/ \mathrm{ml}$. The cells were incubated with $5 \mu 1$ Annexin V-FITC for $15 \mathrm{~min}$ at room temperature without light exposure. Subsequent to the addition of $5 \mu \mathrm{lI}$, flow cytometry was immediately performed using the FACSAria ${ }^{\text {Tin }}$ III system. A total of 10,000 ungated events were acquired for each sample; the data were analyzed with FACSDiva ${ }^{\circledR}$ (version 6.1.3; BD Biosciences).

Protein extraction and immunoblotting. Cells were treated with 25 or $100 \mu \mathrm{g} / \mathrm{ml}$ curcumol or vehicle for $24 \mathrm{~h}$. Following incubation at $37^{\circ} \mathrm{C}$ for $24 \mathrm{~h}$, floating and adherent cells were collected and lysed for $30 \mathrm{~min}$ on ice in radioimmunoprecipitation assay buffer $(150 \mathrm{mM}$ sodium chloride, $1.0 \%$ NP-40, $0.5 \%$ sodium deoxycholate, $0.1 \%$ SDS, $50 \mathrm{mM}$ Tris-pH 8.0) added with $1 \mathrm{mM}$ phenylmethylsulfonyl fluoride, $10 \mu \mathrm{g} / \mathrm{ml}$ leupeptin and $2 \mu \mathrm{g} / \mathrm{ml}$ aprotinin (Sigma-Aldrich; Merck KGaA). Samples were centrifuged at $10,000 \times \mathrm{g}$ at $4^{\circ} \mathrm{C}$ for $10 \mathrm{~min}$ and the supernatants were collected for immunoblotting according to a previously described method (18). In brief, cell lysates (50 $\mu \mathrm{g}$ protein/lane) were resolved in 8-10\% SDS/PAGE gels and transferred to polyvinylidene difluoride membranes (EMD Millipore, Billerica, MA, USA). Membranes were then incubated in a blocking buffer (5\% nonfat milk in $20 \mathrm{mM}$ Tris- $\mathrm{HCl}, 150 \mathrm{mM} \mathrm{NaCl}$, $0.1 \%$ Tween-20) for $1 \mathrm{~h}$ at room temperature and subsequently incubated with the aforementioned primary antibodies in the blocking buffer overnight at $4^{\circ} \mathrm{C}$. Following washing with TBS buffer containing $0.1 \%$ Tween-20, the membranes were incubated with corresponding horseradish-peroxidase conjugated secondary antibodies (as aforementioned) at room temperature for $1 \mathrm{~h}$. The blots were visualized by the use of the aforementioned enhanced chemiluminescent detection kit (Pierce; Thermo Fisher Scientific, Inc.) according to the manufacturer's protocol. The immunoblot bands were quantified by densitometry analysis using Scion Image 4.0 software (Scion Corporation, Frederick, MD, USA) and the signal intensity of each protein was normalized to the corresponding signal intensity of $\beta$-actin. 
$0 \mathrm{~h}$

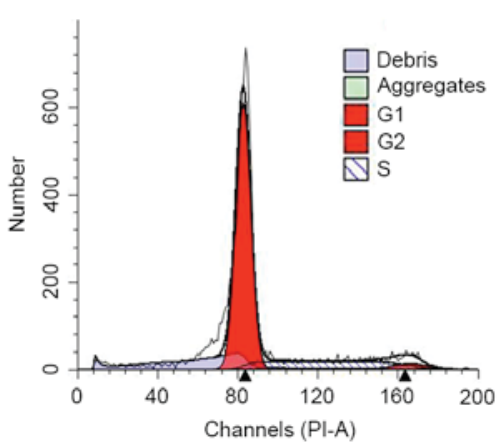

$20 \mathrm{~h}$

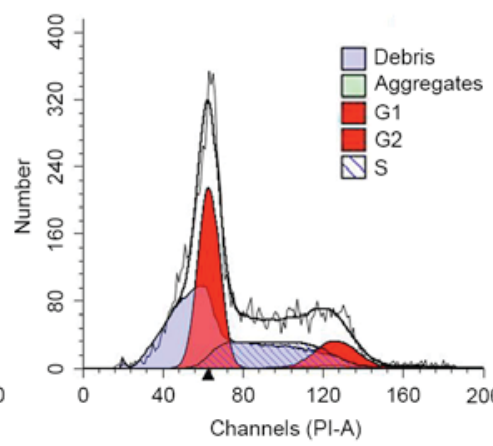

$24 \mathrm{~h}$
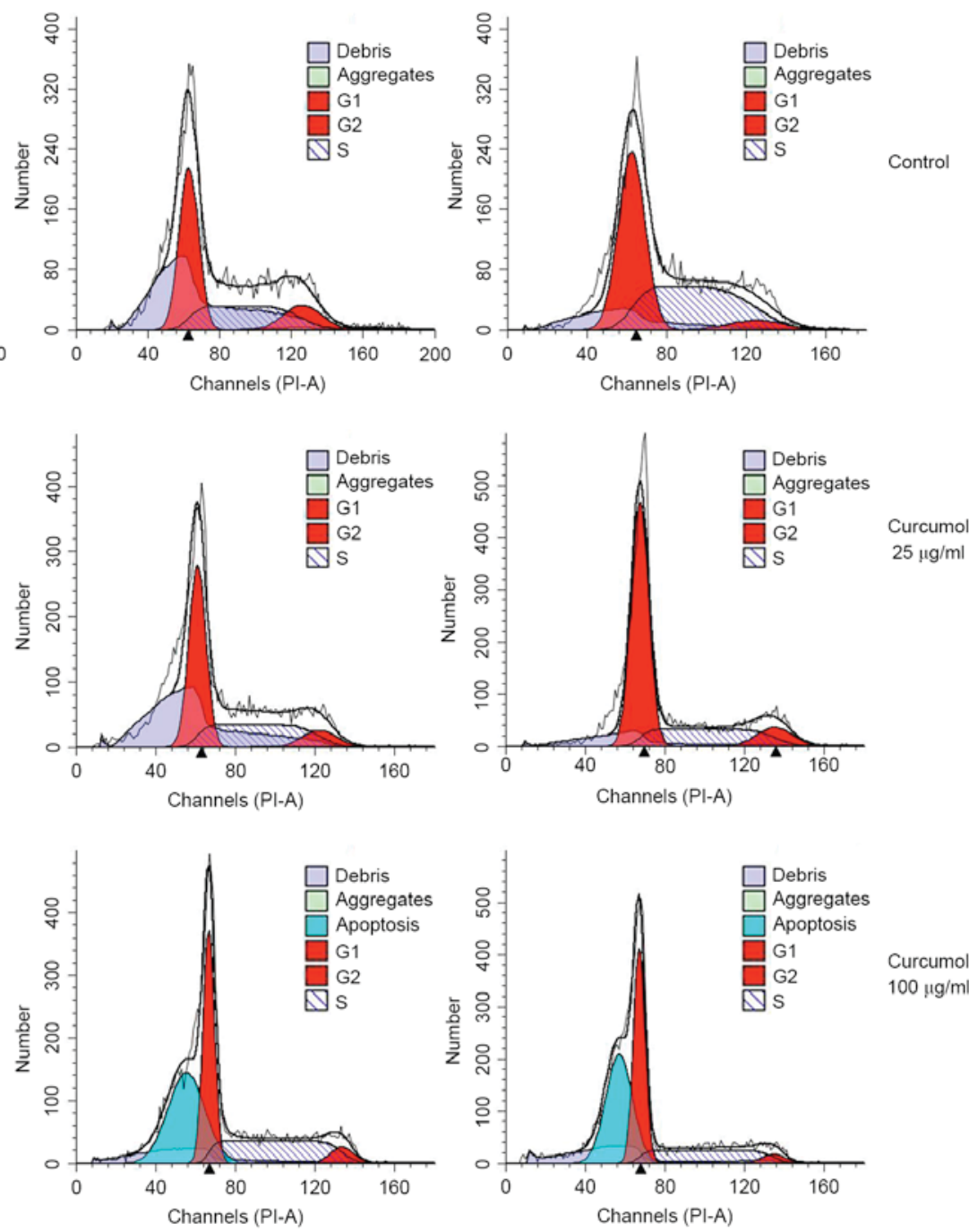

Figure 2. Induction of cell cycle arrest and sub-G1 phase cell accumulation by curcumol in TNBC MDA-MB-231 cells. Following synchronization by serum starvation, MDA-MB-231 cells were stimulated by curcumol $(25$ and $100 \mu \mathrm{g} / \mathrm{ml})$ or vehicle control for 20 or $24 \mathrm{~h}$. $0 \mathrm{~h}$ was the point that cell population was released after the synchronization. Cells were harvested, fixed and stained with PI, and then analyzed for DNA content using flow cytometry. Flow cytometric plots include representative data and indicate that curcumol induced a G1 phase arrest as well as an increase of sub-G1 phase cells. The experiments were repeated $\geq 3$ times and are also presented in Table I. PI, propidium iodide; TNBC, triple-negative breast cancer.

Statistical analysis. The results are presented as the mean \pm standard deviation. One-way analysis of variance was used to evaluate overall difference between the groups. The Student's t-test was performed for pairwise comparison of normal distributed parameters. $\mathrm{P}<0.05$ was considered to indicate a statistically significant difference.

\section{Results}

Curcumol suppresses the growth of TNBC MDA-MB 231 cells in vitro and in vivo. To the best of our knowledge, this is the first time that the effect of curcumol on TNBC MDA-MB-231 cell proliferation has been determined. The cells were treated with 12.5-800 $\mu \mathrm{g} / \mathrm{ml}$ curcumol for 48 and $72 \mathrm{~h}$, and cell viability was examined using an MTT assay. As presented in Fig. 1A, a significant dose- and time-dependent inhibition of TNBC MDA-MB-231 cell proliferation was observed when curcumol was administered at concentrations $>25 \mu \mathrm{g} / \mathrm{ml}$
$(\mathrm{P}<0.05 ; \mathrm{P}<0.01)$. The $\mathrm{IC}_{50}$ value was $240.7 \pm 85.0 \mu \mathrm{g} / \mathrm{ml}$ for $48 \mathrm{~h}$ and $100.2 \pm 13.5 \mu \mathrm{g} / \mathrm{ml}$ for $72 \mathrm{~h}$.

Although recent studies have suggested that curcumol may have anticancer properties, limited in vivo data has previously been presented. Therefore, the present study aimed to explore the effect of curcumol on TNBC MDA-MB-231 xenografts. Two groups of female BALB/C nude mice bearing TNBC MDA-MB 231 xenografts were intraperitoneally injected with curcumol (100 or $200 \mu \mathrm{g} / \mathrm{kg}$ ) every other day for $\leq 21$ days. Compared with the vehicle treatment group, the tumor volume was significantly reduced by $\sim 90.4 \%$ in the $100 \mu \mathrm{g} / \mathrm{kg}$ $(\mathrm{P}=0.0024)$ of curcumol treatment group and by $\sim 97.5 \%$ in the $200 \mu \mathrm{g} / \mathrm{kg}$ group $(\mathrm{P}=0.0009$; Fig. $1 \mathrm{~B}$ and $\mathrm{C})$. Combined, these results suggest that curcumol is capable of blocking the growth of breast cancer TNBC MDA-MB-231 cells in vitro and in vivo.

Curcumol induces $G_{1}$ phase arrest and sub-G $G_{1}$ phase cell accumulation. As the inhibition of cell proliferation may be 
Table I. Induction of $\mathrm{G}_{1}$ arrest and apoptosis in MDA-MB 231 cells by curcumol.

\begin{tabular}{lcccc}
\hline Treatment & $\mathrm{G}_{1}$ & $\mathrm{~S}$ & $\mathrm{G}_{2} / \mathrm{M}$ & Apoptosis \\
\hline $0 \mathrm{~h}$ & $86.95 \pm 3.39$ & $8.51 \pm 2.08$ & $4.53 \pm 1.78$ & $0.00 \pm 0.00$ \\
$20 \mathrm{~h}$ & & & \\
Control & $51.10 \pm 4.32$ & $37.12 \pm 2.34$ & $11.78 \pm 5.87$ & $0.00 \pm 0.00$ \\
$25.0 \mu \mathrm{g} / \mathrm{ml}$ & $56.18 \pm 6.52$ & $32.48 \pm 4.94$ & $11.41 \pm 1.63$ & $0.00 \pm 0.00$ \\
$100.0 \mu \mathrm{g} / \mathrm{ml}$ & $69.21 \pm 17.27$ & $22.20 \pm 10.14$ & $5.26 \pm 4.93$ & $32.96 \pm 10.91^{\mathrm{b}}$ \\
$24 \mathrm{~h}$ & & & & \\
Control & $28.93 \pm 12.34$ & $50.01 \pm 9.54$ & $1.01 \pm 11.25$ & $0.00 \pm 0.00$ \\
$25.0 \mu \mathrm{g} / \mathrm{ml}$ & $33.28 \pm 21.35$ & $48.09 \pm 13.90$ & $18.64 \pm 11.44$ & $0.00 \pm 0.00$ \\
$100.0 \mu \mathrm{g} / \mathrm{ml}$ & $55.15 \pm 10.32^{\mathrm{a}}$ & $38.36 \pm 5.61$ & $6.49 \pm 5.5$ & $41.44 \pm 15.37^{\mathrm{b}}$ \\
\hline
\end{tabular}

Synchronized TNBC MDA-MB-231 cells were stimulated using curcumol (25 and $100 \mu \mathrm{g} / \mathrm{ml}$ ) for 20 or $24 \mathrm{~h}$, stained with propidium iodide and then the cell cycle distribution analyzed by flow cytometry. The $0 \mathrm{~h}$ indicates the release point of synchronized cells. The results are representative of three independent experiments, and data are presented as the mean \pm standard deviation. $\left({ }^{a} \mathrm{P}<0.05\right.$, ${ }^{b} \mathrm{P}<0.01 \mathrm{vs}$. vehicle control.)

due to the arrest of cell growth, the present study investigated the regulatory effects of curcumol on the cell-cycle distribution in TNBC MDA-MB-231 cells. TNBC MDA-MB-231 cells were synchronized by serum starvation as aforementioned. The synchronized cells were stimulated with 25 or $100 \mu \mathrm{g} / \mathrm{ml}$ curcumol for 20 and $24 \mathrm{~h}$ at $37^{\circ} \mathrm{C}$, respectively. The cells were then collected, stained with PI and subjected to flow cytometry analysis. The $0 \mathrm{~h}$ indicates the release point of synchronized cells. The results demonstrated a significant increase in the number of $\mathrm{G}_{1}$ phase cells, from $28.93-55.15 \%$ in the $100 \mu \mathrm{g} / \mathrm{ml}$ treatment group $(\mathrm{P}=0.0240)$, whereas there was only a slight elevation in the group of cells treated with $25 \mu \mathrm{g} / \mathrm{ml}$ curcumol (Fig. 2; Table I). Notably, when the cells were treated with a higher concentration of curcumol $(100 \mu \mathrm{g} / \mathrm{ml}$ for $24 \mathrm{~h})$, $41.44 \%$ of cells were observed to be in the hypodiploid sub- $\mathrm{G}_{1}$ phase, which suggested that the inhibitory effects of curcumol observed in TNBC MDA-MB-231 cells were associated with the induction of apoptosis.

Curcumol induces cell apoptosis. To confirm the aformentioned effect of curcumol on the TNBC MDA-MB-231 cells, the cellular apoptotic response was further investigated via two methodologies. Firstly, the apoptotic morphological features were investigated using DAPI staining. Following exposure to 50,100 or $200 \mu \mathrm{g} / \mathrm{ml}$ curcumol for $48 \mathrm{~h}$, TNBC MDA-MB-231 cells exhibited the following apoptosis-associated morphological changes: Nucleus shrinking, chromatin condensation and the formation of dot-shaped nuclear fragments (Fig. 3A and B). By contrast, the control group was observed to have fewer apoptotic cells.

The present study also confirmed and quantified the apoptotic cells using a flow cytometric Annexin V/PI double staining assay. In the quadrant dot plot of double variable flow cytometry, Q1 quadrant (Annexin V-/PI+) showed necrotic cells; Q2 quadrant (Annexin $\mathrm{V}+/ \mathrm{PI}+$ ) stood for late apoptotic cells; Q3 quadrant (Annexin V-/PI-) showed living cells; and Q4 quadrant (Annexin V+/PI-) represented early apoptotic cells. As presented in Fig. 3C and D, treatment of TNBC MDA-MB-231 cells with 50,100 or $200 \mu \mathrm{g} / \mathrm{ml}$ curcumol increased the early apoptotic cell population (Q4) from $1.8 \pm 0.95 \%$ (vehicle control) to $2.53 \pm 1.05 \%(50 \mu \mathrm{g} / \mathrm{ml}), 4.1 \pm 0.26 \%(100 \mu \mathrm{g} / \mathrm{ml})$ and $12.93 \pm 5.9 \%(200 \mu \mathrm{g} / \mathrm{ml})$, at $18 \mathrm{~h} ; 4.1 \pm 2.6 \%$ (vehicle control) to $5.33 \pm 1.77 \%(50 \mu \mathrm{g} / \mathrm{ml}), 10 \pm 5.04 \%(100 \mu \mathrm{g} / \mathrm{ml})$ and $22.5 \pm 1.58 \%(200 \mu \mathrm{g} / \mathrm{ml})$ at $24 \mathrm{~h} ; 4.2 \pm 2.31 \%$ (vehicle control) to $9.7 \pm 3.43 \%(50 \mu \mathrm{g} / \mathrm{ml}), 19.1 \pm 3.96 \%(100 \mu \mathrm{g} / \mathrm{ml})$ and $27.13 \pm 6.42 \%(200 \mu \mathrm{g} / \mathrm{ml})$ at $36 \mathrm{~h}$. It also increased the late apoptotic cell population (Q2) from $5.96 \pm 3.2 \%$ (vehicle control) to $10.03 \pm 1.8 \%(50 \mu \mathrm{g} / \mathrm{ml}), 11.6 \pm 3.63 \%(100 \mu \mathrm{g} / \mathrm{ml})$ and $15.9 \pm 13.09 \%(200 \mu \mathrm{g} / \mathrm{ml})$ at $18 \mathrm{~h} ; 3.93 \pm 1.55 \%$ (vehicle control) to $10.03 \pm 1.44 \%(50 \mu \mathrm{g} / \mathrm{ml}), 9.8 \pm 3.46 \%(100 \mu \mathrm{g} / \mathrm{ml})$ and $16.83 \pm 5.43 \%(200 \mu \mathrm{g} / \mathrm{ml})$ at $24 \mathrm{~h} ; 7.66 \pm 1.35 \%$ (vehicle control) to $12.68 \pm 2.643 \%(50 \mu \mathrm{g} / \mathrm{ml}), 18.6 \pm 15.73 \%(100 \mu \mathrm{g} / \mathrm{ml})$ and $24.4 \pm 12.34 \%(200 \mu \mathrm{g} / \mathrm{ml})$ at $36 \mathrm{~h}$. These results indicated that curcumol induces a marked level of apoptosis of TNBC MDA-MB-231 cells in a dose- and time-dependent manner.

Curcumol upregulates the expression of p73, PUMA and Bak. Previously published data have demonstrated that p73 may serve a critical role in the induction of cell death by apoptosis in various p53-deficient cancer cell lines, including TNBC 231 cells $(7,19-21)$. In order to understand the events involved in curcumol-mediated apoptosis of TNBC MDA-MB 231-cells, the present study investigated the expression patterns of p73 as well as of the p53-mediated pro-apoptotic mediators PUMA and $\mathrm{Bcl}-2$ associated $\mathrm{X}$ protein (Bax) gene family, using immunoblotting. MCF7 cells, which express wild-type p53 and exhibit overexpression of $\mathrm{p} 53$ and $\mathrm{p} 21$ following exposure to adriamycin $(1 \mu \mathrm{M}, 24 \mathrm{~h})(22)$, were used as a positive control for the immunoblotting. As presented in Fig. 4, treatment with $25 \mu \mathrm{g} / \mathrm{ml}$ curcumol significantly increased $\mathrm{p} 73$ protein expression level $(\mathrm{P}=0.0016)$, and $100 \mu \mathrm{g} / \mathrm{ml}$ curcumol increased the levels of p73, Bak and PUMA proteins $(\mathrm{P}=0.0016$, $\mathrm{P}=0.0263$ and $\mathrm{P}=0.0093$, respectively). No expression of $\mathrm{p} 21$ was detected, which confirmed the dysfunction of p53 in the TNBC MDA-MB-231 cells. The present study was unable to detect the cleaved band of PARP-1 protein in the cells treated with curcumol at the aforementioned dosages, which suggests a caspase-independent apoptosis pathway. Notably, there 
A

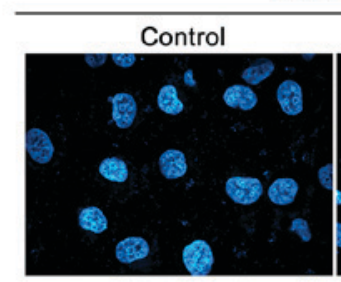

100

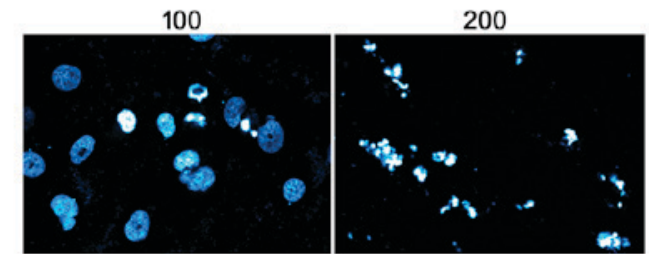

C

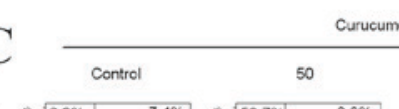

Curucumol (ug/ml)

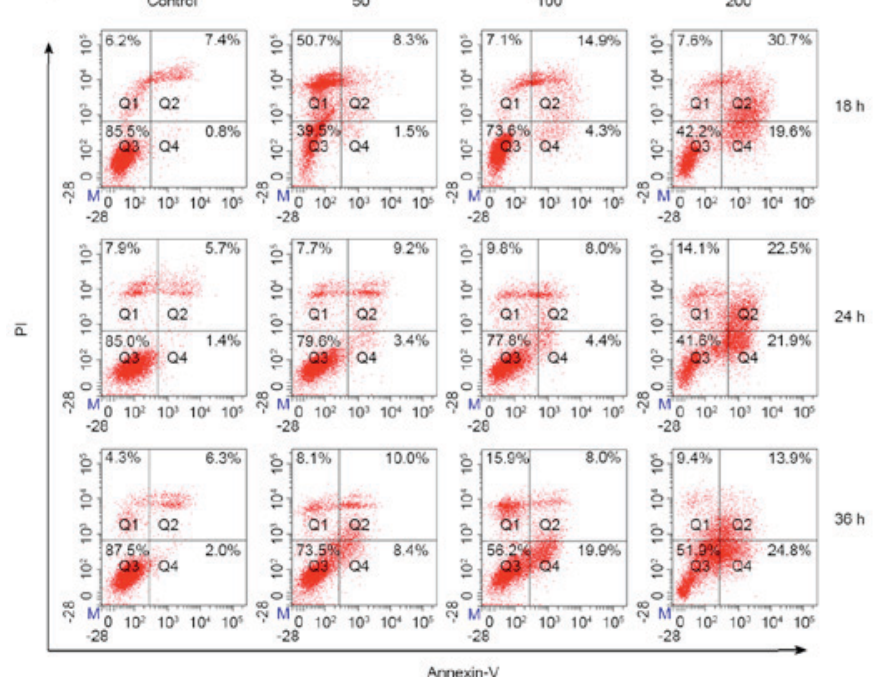

B

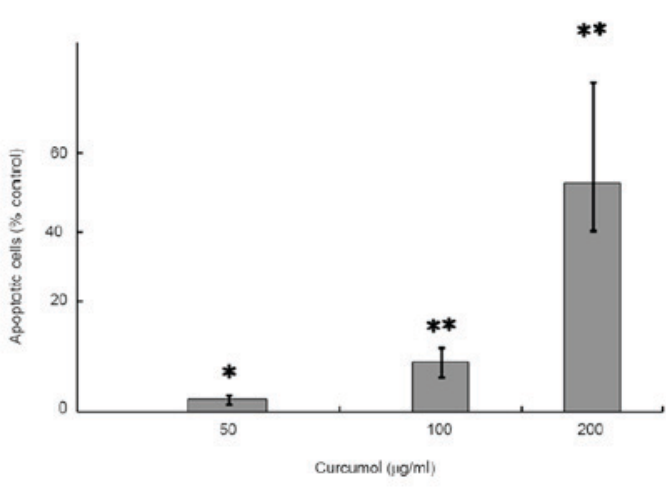

D

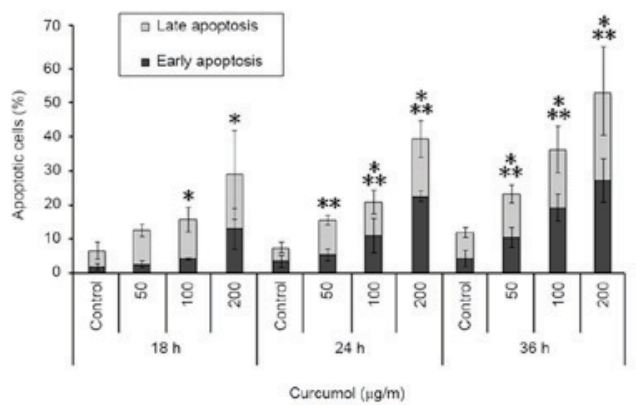

Figure 3. Induction of apoptosis by curcumol in TNBC MDA-MB-231 cells. (A) The percentage of apoptotic cells were increased in MDA-MB-231 cells following exposure to curcumol $(0,50,100$ and $200 \mu \mathrm{g} / \mathrm{ml})$ for $48 \mathrm{~h}$ by DAPI staining. The stained nuclei were observed under a laser confocal fluorescence microscope (original magnification, x400). (B) Summary of apoptotic MDA-MB-231 cells staining with DAPI following treatment with curcumol. Data was obtained by counting the apoptotic cells in $\geq 10$ fields ( $x 400$ ). Each bar represents the mean and the error bars represent the standard deviation of three independent experiments ( $\mathrm{P}<0.05,{ }^{, * *} \mathrm{P}<0.01 \mathrm{vs}$. vehicle control). (C) Representative flow cytometry data demonstrated increased apoptosis rates in cells treated with the indicated concentrations of curcumol for 18, 24 and 48 h. Q1, PI positive (necrosis); Q2, Annexin V and PI positive (late apoptosis); Q3, negative immunofluorescence (living cells); Q4, Annexin V positive (early apoptosis). (D) Summarized data of cell apoptosis. Each bar represents the mean and the error bars represent the standard deviation of three independent experiments. "Early apoptosis, $\mathrm{P}<0.05$ (vs. control); ${ }^{* *}$ Late apoptosis, $\mathrm{P}<0.05$ (vs. control). DAPI, 4,6-diamidino-2-phenylindole; FITC, fluorescein isothiocyanate; PI, propidium iodide; TNBC, triple-negative breast cancer.

was a $35.2 \%$ decrease of p53 expression detected in the cells treated with $100 \mu \mathrm{g} / \mathrm{ml}$ curcumol ( $\mathrm{P}=0.0268$; Fig. 4). These data suggest that curcumol-triggered apoptosis may occur via upregulation of the apoptotic proteins p73, PUMA and Bak and the downregulation of mutant p53 in TNBC MDA-MB 231 cells.

\section{Discussion}

Despite numerous advances in available cancer therapies, TNBC, a subgroup of breast cancer that is often accompanied with higher frequency of p53 gene mutations, remains a challenge in clinical practice due to the lack of biological targets and its resistance to chemo-radiotherapy (1-3). Natural products, particularly those obtained from medicinal herbs, including biochanin A, guercetin and curcumin, with apoptotic activity have attracted great attention as potential sources for the development of novel anticancer drugs (23-25). C. wenyujin, a Chinese traditional herbal medicine, has conventionally been used for the treatment of neoplasm and inflammatory diseases (9). An essential oil from $C$. wenyujin is listed as an anticancer and antiviral drug in the Pharmacopoeia of the P.R. China (11). Curcumol is one of the major pharmacological components of the aforementioned essential oil, and has recently been reported to exhibit an anti-proliferative effect on numerous human tumor cell lines, including lung, breast, ovary, liver, gastric and intestinal cancer (14-17). To the best of our knowledge, the present study is the first to provide evidence of the anticancer effect of curcumol in a p53 mutant TNBC MDA-MB-231 cell line, via demonstrating a direct inhibition of cellular viability and xenograft growth, and the induction of apoptosis.

Apoptosis serves an essential role in cell replacement, tissue remodeling and the removal of damaged cells under normal 


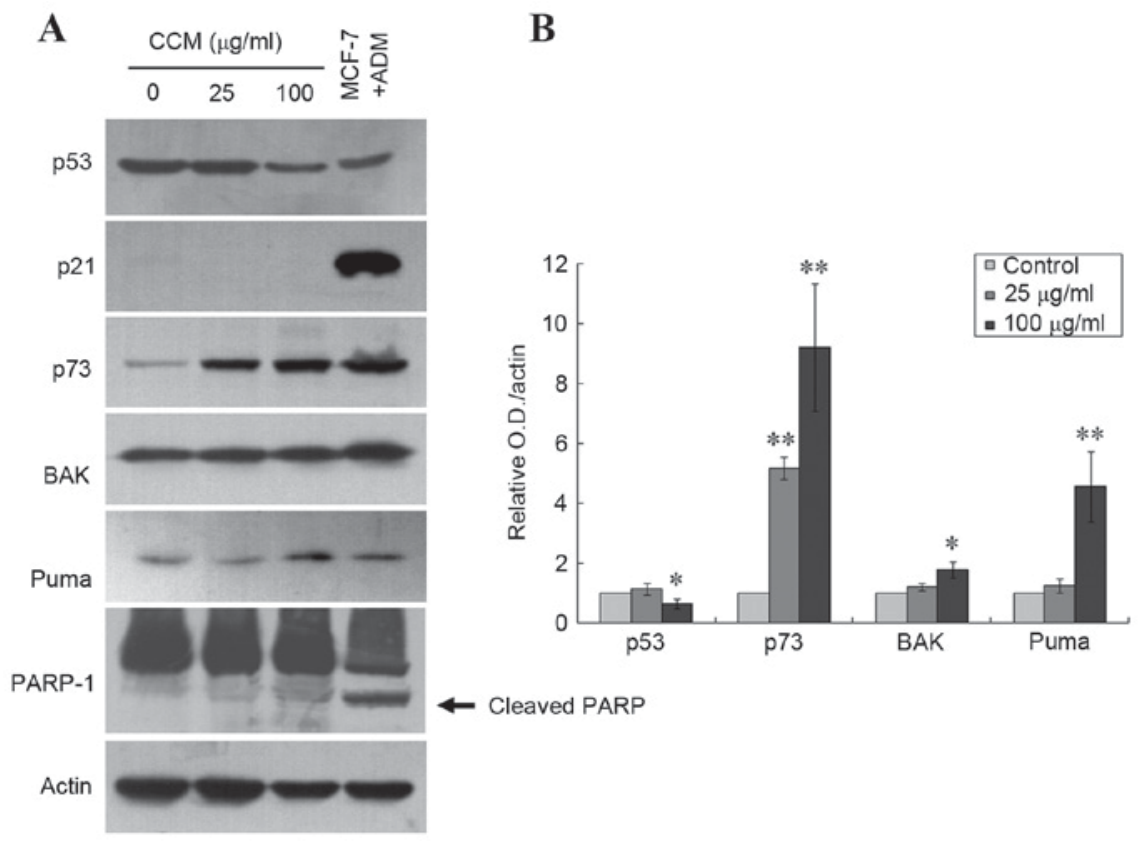

Figure 4. Upregulation of p73, PUMA and Bak expression by curcumol in TNBC MDA-MB-231 cells. (A) Immunoblotting demonstrated increased protein levels of p73, PUMA, Bak and cleaved PARP in MDA-MB-231 cells following treatment with $25 \mathrm{or} 100 \mu \mathrm{g} / \mathrm{ml}$ curcumol for $24 \mathrm{~h}$. Actin was the loading control, and ADM-treated MCF-7 cells served as the antibody controls. Cleavage of PARP is indicated by the arrow. (B) Quantitative data for the relative density of the proteins of interest. Each bar represents the mean \pm standard deviation of three independent experiments $\left({ }^{*} \mathrm{P}<0.05,{ }^{* *} \mathrm{P}<0.01\right.$ vs. the untreated control). PUMA, p53 upregulated modulator of apoptosis; Bak, Bcl-2 antagonistic killer; PARP, poly (ADP-ribose) polymerase; ADM, Adriamycin; MCF, macrophage chemotactic factor; TNBC, triple-negative breast cancer.

conditions. The induction of apoptosis in malignant cells is becoming a practical strategy for cancer treatment $(26,27)$. Thus, signaling pathways involved in enhancing apoptosis are potential targets for identifying innovative drug candidates. There are a number of previous reports demonstrating that the oily extracts of $C$. wenyujin induce cellular apoptosis and inhibit proliferation in certain cancer cell lines (10,28-30). The present study focused on curcumol, one of the active compounds isolated from the curcuma oil (12). Data obtained from flow cytometry and cellular morphology studies demonstrate that curcumol is capable of inhibiting the growth of TNBC MDA-MB 231 cells in a predominantly apoptotic manner. These results are consistent with those observed in various other tumor cell lines (14-17). Furthermore, the present study supported the evidence indicating a marked effect of curcumol in a BALB/c nude mice xenograft model. Therefore, it is postulated that curcumol is capable of inducing apoptosis, which in turn causes tumor cell death.

There are multiple forms of apoptosis; two well-characterized apoptosis signaling pathways are the death receptor pathway and the mitochondrial pathway $(31,33)$. In the death receptor pathway, the binding of death factors, including the Fas ligand, tumor necrosis factor (TNF) or TNF-related apoptosis-inducing ligand, to their corresponding receptors triggers a signaling cascade that results in the activation of initiatorcaspase-8, which in turn activates the downstream effector caspase-3 leading to PARP cleavage (32). The mitochondrial pathway is initiated by $\mathrm{BH} 3$-only proteins that induce the activation and oligomerization of the Bcl-2 family members Bax and Bak (34). The oligomerized Bax/Bak then triggers the release of cytochrome $c$ from mitochondria into the cytosol. Cytochrome c subsequently forms a complex with Apaf-1 and activates caspase- 9 and caspase- $3(33,35)$. As a central integrator of apoptosis signaling pathways, mitochondria also release other pro-apoptotic factors, including apoptosis inducing factor (AIF), triggering a caspase-independent cell death in a Bcl-2-dependent manner (36). The tumor suppressor protein p53 mediates caspase-dependent and caspase-independent cell death through numerous signaling pathways, including the activation of Bcl-2 family member Bax, PUMA or AIF $(37,38)$. The loss of p53 function typically results in the inhibition of apoptotic signaling pathways (39). p21 (CIP1/WAF1) is a regulator of cell cycle progression that is known to be directly activated by wild-type, but not mutant, p53. The lack of p21 expression may serve as an indicator for p53 dysfunction $(40,41)$.

As hypothesized, the expression of p21 in MDA-MB-231 cells following treatment of curcumol was not detected in the present study, but a significant increase in $\mathrm{p} 73$ protein as well as an upregulation of PUMA and Bax expression was observed. p73 is a homolog of p53 and has a vital role in mediating apoptosis in a variety of p53 deficient cancer cells (42-44). In p73-induced apoptosis, p73 triggers the mitochondrial pathway by directly transactivating the Bax and PUMA promoters (42). PUMA belongs to the BH3-only subgroup of the Bcl-2 family. The expression of PUMA promotes the mitochondrial translocation of Bax and formation of the Bax/Bak complex, culminating in the induction of apoptosis (45). Notably, the cleaved band of the PARP-1 protein was not detected in the current study, suggesting that curcumol-induced apoptosis in TNBC MDA-MB-231 cells may be a caspase-independent method of cell death. Furthermore, Zhang et al (17) recently reported that curcumol induces caspase-independent apoptosis through the mitochondrial pathway in human ASTC-a-1 lung adenocarcinoma cells. 
Notably, the present study observed a significant decrease in the expression levels of mutant p53 following curcumol treatment in TNBC MDA-MB-231 cells. Mutant p53 may not only lose tumor suppressive activity, but may also gain functions that promote malignant progression (46). The effect of the downregulation of mutant $\mathrm{p} 53$ protein expression may be associated with its anticancer properties.

The results of the present study have demonstrated the effects of curcumol, including directly suppressing the growth of human p53-mutant TNBC MDA-MB-231 cells via triggering apoptosis. The underlying mechanisms may include an enhancement of p73, which in turn transactivates the expression of PUMA and Bax, and inhibits mutant p53 expression. These results indicate that curcumol may be a promising anticancer compound for further investigation into novel cancer therapeutics, particularly for TNBC.

\section{Acknowledgements}

The present study was supported by the Guangxi Medical Science Research Center Fund (grant no. KFJJ2011-13) and the Guangxi Liver Damage and Repair Key Laboratory Fund (grant no. SYS201307).

\section{References}

1. Turner NC and Reis-Filho JS: Tackling the diversity of triple-negative breast Cancer. Clin Cancer Res 19: 6380-6388, 2013.

2. Oakman C, Viale G and Di Leo A: Management of triple negative breast cancer. Breast 19: 312-321, 2010.

3. Duffy MJ, Synnott NC, McGowan PM, Crown J, O'Connor D and Gallagher WM: p53 as a target for the treatment of cancer. Cancer Treat Rev 40: 1153-1160, 2014.

4. Wang $\mathrm{Z}$ and Sun Y: Targeting p53 for novel anticancer therapy. Transl Oncol 3: 1-12, 2010.

5. Lai D, Visser-Grieve S and Yang X: Tumour suppressor genes in chemotherapeutic drug response. Biosci Rep 32: 361-374, 2012.

6. Jost CA, Marin MC and Kaelin WG Jr: p73 is a simian [correction of human] p53-related protein that can induce apoptosis. Nature 389: 191-194, 1997.

7. Tiwary R, Yu W, Sanders BG and Kline K: $\alpha$-TEA cooperates with chemotherapeutic agents to induce apoptosis of p53 mutant, triple-negative human breast cancer cells via activating p73. Breast Cancer Res 13: R1, 2011.

8. Yoon MK, Ha JH, Lee MS and Chi SW: Structure and apoptotic function of p73. BMB Rep 48: 81-90, 2015.

9. Membership of the 5th Pharmacopoeia Commission: Pharmacopoeia of the People's Republic of China (English edition); Pharmacopeia Commission of PRC, Eds., Chemical Industry Press, Beijing, pp230, 2000.

10. Liju VB, Jeena K and Kuttan R: An evaluation of antioxidant, anti-inflammatory, and antinociceptive activities of essential oil from Curcuma longa. L. Indian J Pharmacol 43: 526-531, 2011.

11. State Pharmacopoeia Commission of P. R. China: Pharmacopoeia Commission of People's Republic of China, China Medicinal Science and Technology Press, Beijing, pp 279, 2005 (In Chinese).

12. Dang YY, Li XC, Zhang QW, Li SP and Wang YT: Preparative isolation and purification of six volatile compounds from essential oil of Curcuma wenyujin using high-performance centrifugal partition chromatography. J Sep Sci 33: 1658-1664, 2010.

13. Hikino H, Meguro K, Sakurai Y and Takemoto T: Structure of curcumol. Chem Pharm Bull (Tokyo) 14: 1241-1249, 1966.

14. Lu JJ, Dang YY, Huang M, Xu WS, Chen XP and Wang YT: Anti-cancer properties of terpenoids isolated from Rhizoma Curcumae-a review. J Ethnopharmacol 143: 406-411, 2012.

15. Guo P, Wang YW, Weng BX, Li XK, Yang SL and Ye FQ: Synthesis, anti-tumor activity, and structure-activity relationships of curcumol derivatives. J Asian Nat Prod Res 16: 53-58, 2014.
16. Tang QL, Guo JQ, Wang QY, Lin HS, Yang ZP, Peng T, Pan XD, Liu B, Wang SJ and Zang LQ: Curcumol induces apoptosis in SPC-A-1 human lung adenocarcinoma cells and displays anti-neoplastic effects in tumor bearing mice. Asian Pac J Cancer Prev 16: 2307-2312, 2015.

17. Zhang W, Wang $\mathrm{Z}$ and Chen $\mathrm{T}$ : Curcumol induces apoptosis via caspases-independent mitochondrial pathway in human lung adenocarcinoma ASTC-a-1 cells. Med Oncol 28: 307-314, 2011.

18. Jiang X, Benovic JL and Wedegaertner PB: Plasma membrane and nuclear localization of $\mathrm{G}$ protein coupled receptor kinase $6 \mathrm{~A}$. Mol Biol Cell 18: 2960-2969, 2007.

19. Yuan R, Meng Q, Hu H, Goldberg ID, Rosen EM and Fan S: P53-independentdownregulation of p73 in human cancer cells treated with Adriamycin. Cancer Chemother Pharmacol 47: 161-169, 2001.

20. Rana S, Gupta K, Gomez J, Matsuyama S, Chakrabarti A, Agarwal ML, Agarwal A, Agarwal MK and Wald DN: Securinine induces p73-dependent apoptosis preferentially in p53-deficient colon cancer cells. FASEB J 24: 2126-2134, 2010.

21. Hong B, Prabhu VV, Zhang S, van den Heuvel AP, Dicker DT, Kopelovich L and El-Deiry WS: Prodigiosin rescues deficient p53 signaling and antitumor effects via upregulating p73 and disrupting its interaction with mutant p53. Cancer Res 74: 1153-1165, 2014.

22. Elmore LW, RehderCW, Di X, McChesney PA, Jackson-Cook CK, Gewirtz DA and Holt SE: Adriamycin-induced senescence in breast tumor cells involves functional p53 and telomere dysfunction. J Biol Chem 277: 35509-35515, 2002.

23. Khan SI, Zhao J, Khan IA, Walker LA and Dasmahapatra AK: Potential utility of natural products as regulators of breast cancer-associated aromatase promoters. Reprod Biol Endocrinol 9: 91, 2011.

24. Greenlee H: Natural products for cancer prevention. Semin Oncol Nurs 28: 29-44, 2012.

25. You L, An R, Liang K and Wang X: Anti-breast cancer agents from Chinese herbal medicines. Mini Rev Med Chem 13: 101-105, 2013.

26. Meyn RE, Milas L and Stephens LC: Apoptosis in tumor biology and therapy. Adv Exp Med Biol 400B: 657-667, 1997.

27. Hassan M, Watari H, AbuAlmaaty A, Ohba Y and Sakuragi N: Apoptosis and molecular targeting therapy in cancer. Biomed Res Int 2014: 150845, 2014.

28. Xiao Y, Yang FQ, Li SP, Hu G, Lee SM and Wang YT: Essential oil of Curcuma wenyujin induces apoptosis in human hepatoma cells. World J Gastroenterol 14: 4309-4318, 2008.

29. Lim CB, Ky N, Ng HM, Hamza MS and Zhao Y: Curcuma wenyujin extract induces apoptosis and inhibits proliferation of human cervical cancer cells in vitro and in vivo. Integr Cancer Ther 9: 36-49, 2010

30. Li Y, Shi X, Zhang J, Zhang X and Martin RC: Hepatic protection and anticancer activity of curcuma: A potential chemopreventive strategy against hepatocellular carcinoma. Int J Oncol 44: 505-513, 2014.

31. Chowdhury I, Tharakan B and Bhat GK: Current concepts in apoptosis: The physiological suicide program revisited. Cell Mol Biol Lett 11: 506-525, 2006.

32. Strasser A, Jost PJ and Nagata S: The many roles of FAS receptor signaling in the immune system. Immunity 30 : 180-192, 2009.

33. Riedl SJ and Salvesen GS: The apoptosome: Signalling platform of cell death. Nat Rev Mol Cell Biol 8: 405-413, 2007.

34. Elkholi R, Floros KV and Chipuk JE: The role of BH3-only proteins in tumor cell development, signaling, and treatment. Genes Cancer 2: 523-537, 2011.

35. Ow YP, Green DR, Hao Z and Mak TW: Cytochrome c: Functions beyond respiration. Nat Rev Mol Cell Biol 9: 532-542, 2008.

36. Pradelli LA, Bénéteau M and Ricci JE: Mitochondrial control of caspase-dependent and -independent cell death. Cell Mol Life Sci 67: 1589-1597, 2010.

37. Estaquier J, Vallette F, Vayssiere JL and Mignotte B: The mitochondrial pathways of apoptosis. Adv Exp Med Biol 942: 157-183, 2012.

38. Ren SX, Shen J, Cheng AS, Lu L, Chan RL, Li ZJ, Wang XJ, Wong CC, Zhang L, Ng SS, et al: Correction: FK-16 derived from the anticancer peptide LL-37 induces caspase-independent apoptosis and autophagic cell death in colon cancer cells. PLoS One 10: e0131750, 2015.

39. Chipuk JE and Green DR. Dissecting p53-dependent apoptosis. Cell Death Differ 13: 994-1002, 2006. 
40. el-Deiry WS, Tokino T, Velculescu VE, Levy DB, Parsons R, Trent JM, Lin D, Mercer WE, Kinzler KW and Vogelstein B: WAF1, a potential mediator of p53 tumor suppression. Cell 75: 817-825, 1993

41. Zhang Z, Huang C, Li J and Shi X: Vanadate-induced cell growth arrest is p53-dependent through activation of p21 in C141 cells. J Inorg Biochem 89: 142-148, 2002.

42. Melino G, Bernassola F, Ranalli M, Yee K, Zong WX, Corazzari M, Knight RA, Green DR, Thompson C and Vousden KH: p73 Induces apoptosis via PUMA transactivation and Bax mitochondrial translocation. J Biol Chem 279: 8076-8083, 2004.

43. Ramadan S, Terrinoni A, Catani MV, Sayan AE, Knight RA, Mueller M, Krammer PH, Melino G and Candi E: p73 inducesapoptosis by different mechanisms. Biochem Biophys Res Commun 331: 713-717, 2005
44. Ming L, Sakaida T, Yue W, Jha A, Zhang L and Yu J: Sp1 and p73 activate PUMA following serum starvation. Carcinogenesis 29: 1878-1884, 2008

45. Yu J, Wang Z, Kinzler KW, Vogelstein B and Zhang L: PUMA mediates the apoptotic response to p53 in colorectal cancer cells. Proc Natl Acad Sci USA 100: 1931-1936, 2003.

46. van Oijen MG and Slootweg PJ: Gain-of-function mutations in the tumor suppressor gene p53. Clin Cancer Res 6: 2138-2145, 2000 . 